IOC.

$1101.60 / 2$ :

768

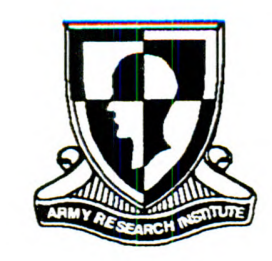

U.S. Army Research Institute for the Behavioral and Social Sciences

Research Report 1768

\title{
The Virtual Sand Table: Intelligent Tutoring for Field Artillery Training
}

Robert A. Wisher and Douglas H. Macpherson

U.S. Army Research Institute

L. Jared Abramson and David M. Thornton

George Mason University

Consortium Research Fellows Program

James J. Dees

U.S. Army Training and Doctrine Command

US Govt. Document

Nondepository

APR 012005
March 2001

Approved for public release; distribution is unlimited. 